\title{
Seroprevalence of TORCH Infections in Pregnant Women Attending Antenatal Clinic in a Tertiary Care Hospital
}

\author{
Kavitha Paul Konikkaraํㅗ Irene Jose Manjiyil2, Vimalraj Angattukuzhiyil Narayanan³, Prithi Nair Kannambra ${ }^{4}$
}

${ }^{1}$ Assistant Professor, Department of Microbiology, Government Medical College, Thrissur, Kerala, India. ${ }^{2}$ Assistant Professor, Department of Microbiology, Government Medical College, Thrissur, Kerala, India. ${ }^{3}$ Additional Professor, Department of Microbiology, Government Medical College, Thrissur, Kerala, India. ${ }^{4}$ Professor and HOD, Department of Microbiology, Government Medical College, Thrissur, Kerala, India.

\section{ABSTRACT}

\section{BACKGROUND}

TORCH infections caused by Toxoplasma gondii, Rubella virus, Cytomegalovirus (CMV) and Herpes simplex Virus (HSV-1 and 2) are often responsible for many unfavourable foetal outcomes like intrauterine growth retardation, congenital anomalies, mental retardation, habitual abortions and still births. As these infections are mild and inapparent, they are rarely diagnosed clinically and are not tested in the pregnant women in the routine antenatal visits. Serological tests remain the method of diagnosis. There is no available baseline data regarding the exact seroprevalence of TORCH infections in our geographical area.

\section{METHODS}

An analytical cross-sectional study was carried out to assess the prevalence of TORCH infections among pregnant women who attended the Antenatal clinic at Government Medical College, Thrissur, Kerala, during a period of one year. Blood samples of 200 pregnant women were analysed for the presence of specific IgG antibodies against each agent of TORCH complex by Enzyme Linked Immunosorbent Assay (ELISA).

\section{RESULTS}

In the present study, specific IgG antibodies for Toxoplasma gondii were detected in $32.5 \%$, for Rubella in 76\%, for $C M V$ in $89.5 \%$, for $H S V-1$ in $43 \%$ and for $H S V-2$ in $8 \%$ of the pregnant women. It was noted that the pregnant women with bad obstetric history $(\mathrm{BOH})$ showed a higher seroprevalence rate than the others. Statistical analysis was done by Chi square test.

\section{CONCLUSIONS}

This study proves that not only pregnant women with BOH but also normal pregnant women are affected by TORCH infections. We recommend that all antenatal cases with $\mathrm{BOH}$ even if they do not have any symptoms should be routinely screened for TORCH agents during the antenatal visits for the proper management of cases. The data reported in our study will be a contribution to the obstetricians and paediatricians of our geographical area to follow appropriate management protocols.

\section{KEY WORDS}

TORCH, Seroprevalence, IgG Antibody, ELISA
Corresponding Author:

Dr. Irene Jose Manjivil,

Assistant Professor,

Department of Microbiology,

Government Medical College,

Thrissur, Kerala, India.

E-mail: drireneantony@gmail.com

DOI: 10.14260/jemds/2019/643

Financial or Other Competing Interests: Dr. Kavitha Paul Konikkara reports grant from State Board of Medical Research (SBMR).

How to Cite This Article:

Konikkara KP, Manjiyil IJ, Narayanan VA, et al. Seroprevalence of torch infections in pregnant women attending antenatal clinic in a tertiary care hospital. J. Evolution Med. Dent. Sci. 2019;8(39):2958-2962, DOI: $10.14260 /$ jemds/2019/643

Submission 03-08-2019,

Peer Review 13-09-2019,

Acceptance 19-09-2019,

Published 30-09-2019. 


\section{BACKGROUND}

Toxoplasma gondii, Rubella virus, Cytomegalovirus (CMV) and Herpes simplex virus (HSV) are the members of TORCH complex causing maternal infections transmitted in utero at different stages of pregnancy. ${ }^{1,2}$ These infections in pregnancy are commonly found in association with poor pregnancy outcomes like habitual abortions, neonatal deaths, intrauterine deaths, still births, intrauterine growth retardation, congenital malformations and other reproductive failures. ${ }^{1,2,3,4,5}$

Toxoplasmosis in humans is caused by an intracellular protozoan parasite Toxoplasma gondii, which is transmitted by contaminated food, water and undercooked meat. Rubella infection is transmitted from mother to fetus through the placenta and from person to person by tiny droplets. Cytomegaloviruses are transmitted by direct contact with saliva, urine, and genital secretions. Transmission of these viruses in pregnant women is by direct contact with infected urine or saliva of young children or through sexual activity. The overall rate of transmission of toxoplasma and $C M V$ infection to the foetus is about $40-45 \% .3,6$ Seroepidemiological studies have shown that $10-20 \%$ of women in childbearing age group in India are susceptible to Rubella infection. ${ }^{7} \mathrm{HSV}-1$ is transmitted by non-sexual contacts while transmission of $H S V$ 2 is always through the sexual route. The usual source of transmission of $H S V$ to the foetus or newborn is the mother. ${ }^{2}$

The prevalence of the TORCH infections changes according to the nutritional factors, socio-cultural habits, geographic factors and route of transmission. 3,4,6,8,9 TORCH infections usually cause minor illness in healthy individuals. As they are initially asymptomatic, they are rarely tested during pregnancy and an early diagnosis on clinical grounds is very unlikely to occur. But, the effect on the foetus can be so severe as these agents can cross the placental barrier to cause intrauterine growth retardation, prematurity, foetal loss or various developmental anomalies and are considered to be a major cause of bad obstetric history (BOH). It is particularly unfortunate as clinical evidence of infection may be detected at birth or not until years later.

Serological tests are the mainstay of diagnosis.[1,2] The diagnosis of acute TORCH infection in pregnant women is usually established by demonstration of specific IgM antibodies or seroconversion in paired sera. Levels of specific IgM antibodies usually decrease after one to six months of infection and become undetectable within seven months. IgG may be detected one to three weeks after the initial rise in IgM level. IgG synthesis reaches a plateau within two or three months and then decreases more or less rapidly and persists lifelong at residual titers.[10,11] A 4 to 8 fold rise in IgG titre in the serum samples taken two weeks apart also indicate a recent infection. A positive IgG titre alone is enough to prove a previous infection with TORCH agents. ${ }^{[3,12]}$

The exact seroprevalence of TORCH infections in India is not known. Since no routine screening for TORCH infections is done for pregnant women in our hospital, no serological data was available regarding the baseline titres in our geographical area. Most of the previous studies in the literature were focused to detect only one or two agents of TORCH complex. So, the present study was undertaken to evaluate the seroprevalence of the agents of TORCH complex- Toxoplasma gondii, Rubella virus, Cytomegalovirus, Herpes simplex Virus -1 and 2 among the pregnant women. This study gives serological evidence of TORCH infections by antenatal screening of specific IgG antibodies among pregnant women with or without BOH.

\section{METHODS}

An analytical cross- sectional study was carried out to assess the seroprevalence of TORCH infections among pregnant women at Government Medical College Thrissur, Kerala. The study was done for a period of one year extending from March 2014 to February 2015. The study was started after getting approval from the Institutional Ethical Committee. Informed consent was obtained from all the pregnant women who were included in our study. The study group included pregnant women who attended the Antenatal clinic of our tertiary care teaching hospital with previous bad obstetric history including unfavourable foetal outcomes in terms of abortions, intrauterine foetal deaths, still births, preterm deliveries, neonatal deaths, intrauterine growth retardation and congenital anomalies and pregnant women without any previous BOH. Pregnant women with other known causes of bad foetal outcomes such as hypertension, diabetes mellitus, eclampsia of pregnancy, $\mathrm{Rh}$ incompatibility and physical causes of abortion were excluded from the study.

A total number of 200 pregnant women were enrolled in the study. Approximately 2-3 $\mathrm{ml}$ of blood was collected from each patient by venepuncture under aseptic precautions and transported to Microbiology laboratory for processing. The blood samples were centrifuged, sera were separated and transferred into sterile vials. As the serum samples were not tested immediately after collection, they were stored at $-20^{\circ} \mathrm{C}$ till the test was performed Three ELISA kits for each test were needed for the study. According to the availability of the kits and collection of serum, testing was done in three different months of the study year. All the serum samples were screened for the presence of specific IgG antibodies against Toxoplasma gondii, Rubella virus, Cytomegalovirus, HSV-1 and HSV- 2 separately in a single serum test by commercially available ELISA test kits manufactured by DSI, Italy. The biomedical waste so generated were disposed-off as per the Bio-Medical Waste Management and Handling rules of 2014. The results were interpreted as per the manufacturer's reference values. All equivocal samples were retested. The results were compiled, and statistical analysis was performed by applying Chi-square test using the Epi Info software (Version 7.5.1.2). 95\% Confidence Interval (CI) was calculated for the positive cases. The risk analysis was performed by calculating Odds Ratio (OR) at $95 \%$ CI. A p value of $<0.05$ was considered to be statistically significant. 


\section{RESULTS}

A total number of 200 pregnant women were tested for specific IgG antibodies against TORCH agents. Out of these, 70 pregnant women were found to have previous $\mathrm{BOH}$ and the rest 130 pregnant women had no previous BOH. In our study, we evaluated the seropositivity of 200 pregnant women for TORCH infections. IgG antibody seropositivity for Toxoplasma gondii was detected in 65 (32.5\%), for Rubella virus in 152 (76\%), for $C M V$ in 179 (89.5\%), for $H S V$-1 in 86 (43\%) and for $H S V-2$ in 16 (8\%) of the pregnant women. (See Table: 1) It was observed that the most frequent TORCH agent detected in the study was $C M V(89.5 \%)$. Table: 2 depicts the seropositivity of specific IgG antibodies against TORCH infections among pregnant women with $\mathrm{BOH}$ and without $\mathrm{BOH}$. It was worth noting that pregnant women with $\mathrm{BOH}$ showed a higher seropositivity than those without BOH. The history of the 70 BOH cases consisted of abortion in 45 (64.2\%), intrauterine growth retardation in (IUGR) in 21 (30\%), intrauterine death in $6(8.6 \%)$, premature labour in $6(8.6 \%)$, neonatal death in $4(5.7 \%)$, and still birth in $1(1.4 \%)$. Odds ratio and $95 \%$ confidence interval was calculated in relation to $\mathrm{BOH}$ to know the risk of exposure of TORCH infections in previous foetal wastages [see Table: 3].

\begin{tabular}{|c|c|c|c|}
\hline $\begin{array}{c}\text { Serological } \\
\text { Test }\end{array}$ & $\begin{array}{l}\text { Total No. of } \\
\text { Cases }\end{array}$ & $\begin{array}{c}\text { No. of } \\
\text { Positive } \\
\text { Cases (\%) }\end{array}$ & $\begin{array}{c}95 \% \\
\text { Confidence } \\
\text { Interval } \\
\end{array}$ \\
\hline Toxoplasma IgG & \multirow{5}{*}{200} & $65(32.5)$ & $25.88-39.12$ \\
\hline Rubella IgG & & $152(76)$ & $69.9-82.04$ \\
\hline Cytomegalovirus IgG & & $179(89.5)$ & $85.16-93.84$ \\
\hline Herpes simplex Virus-1 IgG & & $86(43)$ & $36-50$ \\
\hline Herpes simplex Virus-2 IgG & & $16(8)$ & $4.16-11.84$ \\
\hline
\end{tabular}

Table 1. Seroprevalence of TORCH Infections in Pregnant Women

\begin{tabular}{|c|c|c|}
\hline $\begin{array}{c}\text { Causative } \\
\text { Agent }\end{array}$ & $\begin{array}{c}\text { No. of Positives } \\
\text { for IgG among } \\
\text { Pregnant Women } \\
\text { with BOH } \\
(\mathbf{n = 7 0 )} \mathbf{( \% )}\end{array}$ & $\begin{array}{c}\text { No. of Positives } \\
\text { for IgG among } \\
\text { Pregnant Women } \\
\text { without BOH } \\
(\mathbf{n = 1 3 0 )}(\mathbf{\% )})\end{array}$ \\
\hline Toxoplasma gondii & $30(42.9 \%)$ & $35(26.9 \%)$ \\
\hline Rubella virus & $59(84.3 \%)$ & $93(71.5 \%)$ \\
\hline$C M V$ & $68(97 \%)$ & $111(85.4 \%)$ \\
\hline$H S V-1$ & $34(48.6 \%)$ & $52(40 \%)$ \\
\hline$H S V-2$ & $7(10 \%)$ & $9(6.9 \%)$ \\
\hline \multicolumn{2}{|c|}{ Table 2. Comparison of Results of Pregnant Women } \\
with BOH and without BOH \\
\hline
\end{tabular}

\begin{tabular}{|c|c|c|c|}
\hline $\begin{array}{c}\text { Type of Torch } \\
\text { Infection }\end{array}$ & Odds Ratio & $\begin{array}{c}\text { 95\% Confidence } \\
\text { Interval of } \\
\text { Odds Ratio }\end{array}$ & p Value \\
\hline Toxoplasma gondii & 2.03 & $1.1-3.7$ & $0.02(\mathrm{~S})$ \\
\hline Rubella & 2.1 & $1.01-4.5$ & $0.04(\mathrm{~S})$ \\
\hline CMV & 5.8 & $1.3-25.7$ & $0.19(\mathrm{NS})$ \\
\hline$H S V 1$ & 1.4 & $0.78-2.5$ & $0.30(\mathrm{NS})$ \\
\hline$H S V 2$ & 1.4 & $0.5-4.1$ & $0.62(\mathrm{NS})$ \\
\hline \multicolumn{3}{|c|}{ Table 3. Association of BOH in TORCH Infections } \\
(S) Significant (NS) Non-Significant \\
\hline
\end{tabular}

\section{DISCUSSION}

The main aim of our study was to identify the pregnant women infected with TORCH agents. The study showed a high rate of seroprevalence for TORCH infections. We also identified women with BOH showing a higher IgG positivity for all TORCH agents which may be due to previous exposures (See Table: 2). In our study, the seroprevalence rate of Toxoplasma gondii specific IgG antibody was found to be $32.5 \%$. Turbadkar et al reported a seropositivity rate of $42.1 \%$ in women with $\mathrm{BOH}$. Nearly $35.6 \%$ of the pregnant Saudi women exhibited specific IgG antibodies to Toxoplasma gondii as reported by Hani et al. ${ }^{13}$ High prevalence rates were obtained in studies done by Zemene et al (81.1\%) ${ }^{14}$ and Sroka et al (68.6\%). ${ }^{15} \mathrm{~A}$ lower prevalence rates were reported in studies by Song et al $(0.79 \%)^{16}$ and Jenum et al (10.9\%).17 A decrease in the prevalence rates in these studies may be due to their very large sample size.

We found a high seroprevalence rate (76\%) of Rubella IgG antibody. Rubella seroprevalence rate was high in studies reported from Jeddah (91.6\%) ${ }^{8}$ and Tanzania (92.6\%). ${ }^{18}$ We could not obtain a reliable history of immunisation status against Rubella from our patients. So, we could not exclude the possibility of a high prevalence rate of IgG antibody following Rubella vaccination. The high prevalence of Rubella IgG antibodies (93.3\%) among pregnant women of Saudi suggesting a successful vaccination campaign was reported by Hani et al. ${ }^{13}$ Vaccination against Rubella in adolescence can result in adequate immunity in the women of childbearing age.

The high prevalence rate of $C M V$ obtained in our study $(89.5 \%)$ agreed with the study reported by Turbadkar et al $(91.05 \%)^{2}$ and Hani et al (92.1\%).13 This denoted that $C M V$ was very common and unidentified in our community. Even though the $\mathrm{p}$ value was not significant the high rate of $C M V$ seropositivity in $\mathrm{BOH}$ cases shows the apparent risk of $C M V$ infection in pregnant women with bad obstetric history. Interpretation of high rate of seropositive $C M V$ required understanding the fact that $C M V$ has the capability to persist as latent infection indefinitely in the human host particularly in several glands and kidneys. ${ }^{19}$ Serological surveys conducted in different parts of India has documented $80-90 \%$ prevalence of IgG CMV antibodies in the women of childbearing age. ${ }^{20}$ In the current study, seroprevalence rate of $H S V-1$ was $43 \%$ which was relatively low when compared to the study done by Obeid et al (93.2\%). ${ }^{9}$ Regarding $H S V$-2 positivity, rate of Ig G antibody was too high in a study done in Turkey (63\%)21 compared to our study (8\%). A stud y done at Northeast India has reported a seroprevalence rate of $8.7 \%$ which is similar to our findings. ${ }^{22}$ As $H S V-2$ is a sexually transmitted disease, awareness of spread of HIV infection might have affected the prevalence rate of $H S V$-2. In a long term study spanning from 1989 to 2010 Delaney et al showed that there is a declining trend of $H S V-2$ infection among pregnant women. ${ }^{23}$ Also, he found that the seroprevalence of $H S V-2$ infection has come down from 30.1\% (During 1989 to 1999) to 16.3\% (during 2000 to 2010).23

95\% Confidence Interval of the seroprevalence rate of all the TORCH agents (See Table: 1) showed a narrow range, therefore precision is more in descriptive results. We analysed the Odds Ratio of each TORCH components to find out the association of $\mathrm{BOH}$ against TORCHinfections. This shows an apparent relationship between TORCH agents and BOH (See Table: 2). None of our subjects were previously symptomatic. It indicates that subclinical or asymptomatic infection was prevalent in our community.

\section{Limitations}

We could not test paired sera samples after two weeks to follow up the rise in titre of IgG antibodies. We could not test 
for detection of IgM antibodies to exclude recent infection as a part of our study. We also could not do follow up of our cases till their obstetric outcome even though we enquired about $\mathrm{BOH}$ for their previous pregnancies. This could have given additional information about the actual burden of the infections.

\section{CONCLUSIONS}

This study proves that not only pregnant women with BOH but also normal pregnant women are affected by TORCH infections. In the absence of a national screening programme in India for TORCH infections during pregnancy, serological detection for TORCH infections remains the only means for detecting such infections. The pattern of investigations for pregnant women has to be changed by incorporating TORCH screening tests also in their routine antenatal check-ups. We recommend that all the antenatal cases with $\mathrm{BOH}$ even if they do not have any symptoms should be routinely screened for TORCH agents. This helps in the early diagnosis and appropriate intervention in managing the cases. The data reported in our study will be a contribution to the obstetricians and paediatricians of our geographical area to make appropriate management protocols. This knowledge will help the clinicians to counsel the mothers on preventive measures taken to avoid such infections.

\section{ACKNOWLEDGEMENT}

We are very thankful to State Board of Medical Research (SBMR) for giving the financial support for the study.

\section{REFERENCES}

[1] Sen MR, Shukla BN, Tuhina B. Prevalence of serum antibodies to TORCH infection in and around Varanasi, Northern India. J Clin Diag Res 2012;6(9):1483-5.

[2] Turbadkar D, Mathur M, Rele M. Seroprevalence of TORCH infection in Bad obstetric history. Indian J Med Microbiol 2003;21(2):108-10.

[3] Sarkar MD, Anuradha B, Sharma N, et al. Seropositivity of Toxoplasmosis in antenatal women with bad obstetric history in a tertiary care hospital of Andhra Pradesh, India. J Health Popul Nutr 2012;30(1):87-92.

[4] Kumari N, Morris N, Dutta R. Is screening of TORCH worthwhile in women with bad obstetric history: an observation from eastern Nepal. J Health Popul Nutr 2011;29(1):77-80.

[5] Wu D, Wu Y, Wang L, et al. Evaluation of a novel array- based toxoplasma, Rubella, cyto megalovirus and Herpes simplex virus IgG enzyme linked immunosorbent assay and its comparison with virion/serion Enzyme linked immunosorbent assays. Ann Lab Med 2014;34(1):38-42.
[6] Nyholm JL, Schleiss MR. Prevention of maternal Cytomegalovirus infection: current status and future prospects. Inter J Womens Health 2010;2:23-35.

[7] Ramana BV, Reddy K, Murty DS, et al. Seroprevalence of Rubella in women with bad obstetric history. J Fam Med Primary Care 2013;2(1):44-6.

[8] Alsibiani SA. Rubella immunity among pregnant women in Jeddah, Western region of Saudi Arabia. Article ID 659838, Obstet Gynecol Int 2014;2014: p. 6.

[9] Obeid OE. Prevalence of Herpes simplex virus types 1 and 2 and associated sociodemographic variables in pregnant women attending King Fahd hospital of the University. J Family Community Med 2007;14(1):3-7.

[10] Robert-Gangneux F, Darde ML. Epidemiology of and diagnostic strategies for toxoplasmosis. Clin Microbiol Rev 2012;25(2):264-96.

[11] Gras L, Gilbert RE, Wallon M, et al. Duration of the IgM response in women acquiring Toxoplasma gondii during pregnancy: Implications for clinical practice and crosssectional incidence studies. Epidemiol Infect 2004;132(3):541-8.

[12] Razzak AH, Wais SA, Saeid AY. Toxoplasmosis: the innocent suspect of pregnancy wastage in Duhok, Iraq. Eas Med Health J 2005;11(4):625-32.

[13] Hani OG, Abdulwahab MT, Maho med FM. TORCH agents in pregnant Saudi women. Med Principles Pract 2002;11(4):180-2.

[14] Zemene E, Yewhalaw D, Abera S, et al. Seroprevalence of Toxoplasma gondii and associated risk factors among pregnant women in Jimma town, South western Ethiopia. BMC Infect Dis 2012;12:337.

[15] Sroka S, Bartelheimer N, Winter A, et al. Prevalence and risk factors of Toxoplasmosis among pregnant women in Fortaleza Northern Brazil. Am J Trop Med Hyg 2010;83(3):528-33.

[16] Song KJ, Shin JC, Shin HJ, et al. Seroprevalence of toxoplasmosis in Korean pregnant women. Korean J Parasitol 2005;43(2):69-71.

[17] Jenum PA, Kapperud G, Stray-Pedersen B, et al. Prevalence of Toxoplasma gondii specific immunoglobulin $\mathrm{G}$ antibodies among pregnant women in Norway. Epidemiol Infect 1998;120(1):87-92.

[18] Mwambe B, Mirambo MM, Mshana SE, et al. Seropositivity rate of Rubella and associated factors among pregnant women attending antenatal care in Mwanza, Tanzania. BMC Pregnancy Childbirth 2014;14:95.

[19] Mohammed EAK, Salman YJ. Study of TORCH infections in women with Bad Obstetric History (BOH) in Kirkuk city. Int J Curr Microbiol App Sci 2014;3(10):700-9.

[20] Gandhoke I, Aggarwal R, Lal S, et al. Congenital CMV infection in sympto matic infants in Delhi and surrounding areas. Indian J Pediatr 2006;73(12):10957.

[21] Duran N, Yarkin F, Evruke C, et al. Asymptomatic Herpes simplex virus type $2(\mathrm{HSV}-2)$ infection among pregnant women in Turkey. Indian J Med Res 2004;120(2):10610. 
[22] Biswas D, Borkakoty B, Mahanta J, et al. Seroprevalence and risk factors of Herpes simplex virus type-2 infection among pregnant women in Northeast India. BMC Infectious Diseases 2011;11:325.
[23] Delaney S, Gardella RC, Saracino M, et al. Seroprevalence of Herpes simplex virus types 1 and 2 among pregnant women, 1989-2010. JAMA 2014;312(7):746-8 